\title{
Introduction: Bigmanity and network governance in African conflicts
}

Mats Utas

This volume invites comparisons across the African continent by presenting case studies from a variety of countries, settings and institutions with one factor in common: armed conflict. ${ }^{1}$ The chapters that follow refer to sociopolitical or economic networks along a continuum from formal and open to informal and at times even illicit. $^{2}$ It has been argued that networks will rise to prominence where formal states, or other sovereign entities, are fractured, weak or barely present (Reno 1998). Informal networks of political or economic character are present in any society, whether in Africa, Europe, North America or elsewhere. The politics of intimacy, or 'the culture of intimacy', as Herzfeld (1997) would have it, is part of the everyday life of nation-states where every institution is governed by onstage and offstage politics (Shryock 2004; Goffman 1959). It is the inner workings of politics and the ever-present backrooms to the official storefronts of political and economic ventures which are central in this volume. A second theme running through the book concerns the role of Big Men, informal political and/or economic actors situated in social space. ${ }^{3}$ Big Men will be treated here as nodes in networks, combining efforts in projects of joint action. Joint action may be economic or political, and could for instance be a war effort.

The combination of Big Men and networks is not an African phenomenon, but rather a very human enterprise. Works concerned with African neo-patrimonialism, clientelism and patron-client systems are many, but I intend in this introduction to approach from a somewhat different angle by fusing classic network studies with Big Men/Great Men research originating from Melanesia (e.g. Sahlins 1963; Godelier 1986; Godelier and Strathern 1991). The term is, furthermore, used emically; for instance, in Sierra Leone people constantly refer to Big Men and their ways of acting, systematically relating to who is, and who is not, a Big Man in all social settings.

Early in For the City Yet to Come (2004b), AbdouMaliq Simone notes that when working with NGOs in urban Africa, he was always bewildered that staff seldom appeared to be doing what they were hired to do; instead, the work that was in fact achieved was described as being done somewhere else. In his quest for locating this 'somewhere else', Simone notes that by engaging with 
these organizations 'over an extended period of time, it became clear that there were other, more provisional and ephemeral, forms of ... collective activity that association members also participated in and that seemingly had a greater impact on their life' (ibid.: 24). This is what Chabal and Daloz, although from slightly different vantage points and reaching somewhat different conclusions, talk about as Africa Works (1999). But in zones of conflict and war, where everything is in flux, the inner workings of 'order' are even more intricate. War in Africa does not imply the collapse of everything, a venturing into total anarchy. Alternative forms of control and management establish themselves when formal governance is diminished. These may be in the guise of rebel movements and militias, often mimicking the formal, or of more fluid forms of network. Two examples from the first war in Liberia and the early period of the war in Somalia highlight this point. The currency in the so-called greater Liberia, Charles Taylor and NPFL territory, maintained twice the value of the new, official Liberian currency introduced early in the war. By issuing a new currency and upholding a ban on trading in the old, the interim government and the international community had intended to starve Taylor and the NPFL out but, owing to informal structures of governance within greater Liberia, the result turned into the opposite. A second, related example is the way in which Somalia, without state or central bank, maintained a relatively stable currency during the first part of the war. This was possible, Peter Little (2003) remarks, because of networks of money-changers and informal finance houses. These examples demonstrate how other, and alternative, power structures maintain a degree of order in conflict zones. In fact, conflict opens up space for new alternative political and economic structures that reach far beyond the conflict zone itself, as in this recent example from Somalia:

Somali networks criss-cross the Horn of Africa and, as states in East Africa seek to develop economic links, their experience shows that such links already exist, at least informally. Finance from Mogadishu, distribution networks fanning out from Nairobi and agents across the region paint the picture of an increasingly connected economy. The clan- and family-based nature of Somali business networks means that there is ample scope for developing new markets and connections wherever Somali communities are present. It must also be noted that Somali networks extend into Europe, North America, the Gulf states and beyond, demonstrating the continuing connectedness of this widely dispersed community. (Abdulsamed 2011: 15)

\section{The African state and other forms of governance}

There is already a considerable state-centric literature on conflicts and other outcomes of the crisis of the post-colonial Westphalian state in Africa, whether labelled failed, collapsed, weak or fragile (see, among many others, Bøås and 
Dunn 2007; Bayart et al. 1999; Duffield 2001; Kaldor 1999; Reno 1995, 1998; Andersen et al. 2007; Chabal and Daloz 1999). Although many of the chapters in this volume discuss this, in this introduction I avoid such discussions. Suffice it to say that weak African states have opened up space for alternative sources of sovereignty (Hansen and Stepputat 2005) and alternative forms of governance (Utas 2009), as well as allowing ample room for violent contestations over the state in the form of military coups and armed incursions (Biró 2007; Reno 1998; Bøås and Dunn 2007; Clapham 1998). One could argue that most African states have never been more than nominally sovereign and that weak states have necessitated considerable use of violence (Mbembe 2001, 2003; Utas 2009) as well as rhizomically informal and alternative, although not necessarily opposing, structures of governance (Bayart 1993). It is essential to point out that state and civil society are intricately interconnected and interwoven and cannot be understood in opposition to each other. Neither state nor civil society is democratic in its basic set-up. The state in many African countries, Ferguson points out, 'starts to look suspiciously like civil society' (2006: 99), and civil society appears as a number of political entities, or integrated 'parts of a new, transnational apparatus of governmentality' (ibid.: 103). ${ }^{4}$ These political entities do not replace nation-states and national governance but overlay them and coexist.

Citizens in many African states - states in the Westphalian Periphery (Biró 2007) - have an ambivalent relationship with the state. AbdouMaliq Simone remarks that in Senegal 'many urban dwellers will come to feel locked in by the frequently overbearing demands of these practices and institutions' (Simone 2004b: 36). From a predominantly economic perspective he notes that unconventional trade, involving well-off business persons, soldiers, militias, middlemen of various nationalities and petty traders, is most common within states where chronic political crisis has undermined state regulations and where civil servants in formal institutions continue to function and maintain some control by their very activities in informal trade (ibid.: 25 ). ${ }^{5}$ The informal logic of daily life rests on what Simone calls 'the spectral order of things' (ibid.: 92ff.), a politico-economic blending, or a métissage of relations penetrating society so thoroughly that, for instance, the regime that has ruled Cameroon for the last twenty years 'increasingly recognizes that it need no longer substantially invest in the definitional aspects of rule - that is, to deliberate clearly defined jurisdictions, zones, policies, and sectors' (ibid.: 94b). The spectral order of things is deemed more efficient and possibly the only viable path.

Simone, along with many other observers, locates such 'failures' in historic perspectives and points out that, in order to make colonies productive, the objective of colonizing states was 'to access labor without encouraging wage labor' (ibid.: 144). In Central Africa it was frequently concessionary companies which carried administrative costs, leading towards more businesslike state 
formations. Local order was disrupted in order to intensify authoritarian control, with the effect of '[a] loosening of the population from its former social and political ties ... giving rise to populations accountable to no one' (ibid.: 145). Polities, Simone further states, became "largely based on "big man" systems operating more as commercial firms than as states' (ibid.). This gives us a glimpse of the roots of Big Men networks, made possible, if not necessary, by political changes on the continent as a partial consequence of colonialism and related politico-economic endeavours of conquest. ${ }^{6}$

According to Alex de Waal, the most complicated conflicts in the contemporary world are found in countries where state institutions are subordinate to patronage networks. Without denying the fact that citizens care about political issues and do fight over them, he states that people 'can neither organize their political allegiances through rule-governed organizations nor resolve them through state institutions according to the rule of law' (de Waal 2009: 99). In his view, political life in most African countries is organized as 'a patrimonial marketplace', operating according to socioculturally established conventions. Depending on the perspective of the viewer, the result can be described both as 'state failure/fragility and as an alternative way in which countries can function' (ibid.).

De Waal takes his cue from Samuel Huntington, who some forty years ago pointed out that " $[\mathrm{t}]$ he most important political distinction among countries concerns not their form of government but their degree of government' (ibid.). In this light, it is formal organizational voids which are crucial, not differences in socioculture per se. At this point, one could question de Waal's cultural use of neo-patrimonialism, given his reference to Huntington's structural and thus universally valid perspective. According to de Waal,

$[\mathrm{u}]$ nder such systems, some insist that 'Africa works' and will continue to do so. This strand of thought does not deny that people, including political leaders, hold strong political beliefs. It is just that the vehicles available to promote these political agendas, such as political parties, legislatures and government ministries, operate according to socio-cultural rules, notably patrimonialism. (De Waal 2009: 101)

But why socioculture? Have all countries with weak states the same sociocultural traits? De Waal ends up with many of the same problems as Bratton and van de Walle, for whom neo-patrimonialism is 'the distinctive institutional hallmark of African regimes' (Bratton and van de Walle in Mkandawire 2002: 184), where 'neopatrimonial regimes [are] ... embedded in precapitalist societies' (Bratton and van de Walle 1997: 89). ${ }^{7}$ By contrast, we see Big Men and networks of governance not as sociocultural features but rather as socio-structural ones, where certain structural features prescribe certain social outcomes. Naturally, networks are social and cultural manifestations as much as they are politi- 
cal and economic (as Roitman points out in Duffield 2002: 160), but such manifestations differ from setting to setting. To reiterate: with weak or absent state institutions the structural alternative is more influential and stronger informal networks governance, whether in Liberia, Italy or the United States. For instance, organized criminals are connected with governance structures and formal private enterprises in every country, but the structural void created during armed conflict and war increases the space for such nodes. Yet informal Big Man networks are far from just criminal, as I argue below.

Many Africans remain sceptical about their own state; some are downright hostile. Are they citizens or subjects (Mamdani 1996), or neither (Fanthorpe 2001)? On the African continent, new groups rage against the machine (Bøås and Dunn 2007), turn abject heroes, antisocial by necessity (Utas 2008a), or just hustle the system (Christensen and Utas 2008; Utas and Jörgel 2008). In Sierra Leone and Liberia, but most recently among the Somali diaspora in Nairobi, I have researched how people affected by war arrange themselves in various local, and chiefly informal, organizations around both social and physical security, protecting themselves in part against the state and emissaries of the state. Frequently they take the form of small-scale and semi-sovereign organizations that tend to mimic the functioning state, but on a micro level. Although they organize themselves in opposition to the state to some extent, both individuals and sometimes entire organizations cultivate extensive ties with civil servants, with rhizomes reaching deep into the centre of the state (as pointed out in this volume; in particular Chapters 1, 3, 4 and 9). Such organizations are urban phenomena, although rhizomes and local cuttings certainly reach into rural areas, in particular into resource-rich mining areas, rural towns and borderlands (see Chapters 1,2 and 5 in this volume) connected not only to urban but also to global networks (see Chapters 6 and 10).

In what might appear fleetingly, especially to a scholar of government, to be the ruins of urban life, a social infrastructure still exists, says Simone. Such infrastructure facilitates intersections of socialities used by citizens who possess limited other means (Simone 2004a: 407). He points out how 'residents' reciprocal efforts are radically open, flexible, and provisional' and thus 'a specific economy of perception and collaborative practice is constituted through the capacity of individuals to circulate across and become familiar with a broad range of spatial, residential, economic, and transactional positions' (ibid.: 408). Simone proposes that we should see people themselves as infrastructure (ibid.: 407, 410-11).

It is always possible to do something different with the city, or the state for that matter, from what it is intended for; it is possible to keep the official structure operative, using official space for private entrepreneuring (ibid.: 409). For instance, the minister of aviation in an African country formally prevents illicit goods going through the national airport, but informally uses the same 
structures to facilitate the smuggling of cocaine. Commonplace traders are using an official storefront to sell construction material but double as dealers in so-called blood diamonds, and get a cut from the prolific trade in arms and ammunition destined for a neighbouring country in armed conflict. It is the combination of activities and people which is creating alternative modes of production. Such institutional forms constitute

highly mobile and provisional possibilities for how people live and make things, how they use the urban environment and collaborate with one another. The specific operations and scopes of these conjunctions are constantly negotiated and depend on the particular histories, understandings, networks, styles, and inclinations of the actors involved. (Ibid.: 410)

It is, in this telling, the reweaving of connections, both local and international, which makes Africa work, and it is these conjunctions and network textures which are of interest in this book, networks that are systems of both 'politics and resource provision' (Simone 2004b: 42). If networks are alternative modes of governance, then Big Men are alternative governors of peopled infrastructures.

\section{Big Men}

Marshall Sahlins, in an article from 1963, states that '[t]he Melanesian bigman seems so thoroughly bourgeois, so reminiscent of the free enterprising rugged individual of our own heritage. He combines with an ostensible interest in the general welfare a more profound measure of self-interested cunning and economic calculation' (Sahlins 1963: 289). There are a number of characteristics that he attaches to the Big Man, many universally valid and easily adaptable to African scenarios. '[T] he indicative quality of big-man authority', he states,

is everywhere the same: it is personal power. Big-men do not come to office; they do not succeed to, nor are they installed in, existing positions of leadership over political groups. The attainment of big-man status is rather the outcome of a series of acts which elevate a person above the common herd and attract him a coterie of loyal, lesser men. (Ibid.: 289)

The Big Man has the ability to command, to instigate mass action, where authority is not structurally ascribed and socio-historically motivated but based on the Big Man's ability to create a following and to a large extent dependent on his informal abilities to assist people privately. The creation of his own faction is absolutely crucial for his power and standing (ibid.: 29of.), and upward mobility occurs when he connects other men and their families to his faction, 'harnessing their production to his ambition' (ibid.: 292). Building renown and power is based on amassing wealth and redistributing it with 'astutely calculated generosity' (Godelier 1986: 163).

Sahlins asserts the fragility and the temporality of Big Man power, as loyalty 
must continuously be reinforced and dissatisfaction among followers may have grave consequences for his authority (Sahlins 1963: 292), which leads to what Sahlins calls a 'comparative instability' (ibid.: 293). The death of an important Big Man, for instance, may lead to a regional political 'trauma' as factions are built around a particular Big Man and a whole network may temporarily dissolve, eventually being rebuilt around other Big Men. A further source of instability is what Sahlins calls 'the Melanesian contradiction' (ibid.): economic reciprocity between the Big Man and his followers on one side, but on the other hand there is cumulative build-up of a Big Man that eventually will lead to extortion of the faction (ibid.). There is thus an obvious risk that a Big Man will overburden his followers, leading to 'the generation of antagonisms, defections, and in extreme cases the violent liquidation of the center-man' (ibid.). As Godelier notes, the Big Man is thus 'little by little undermining his social base' (1986: 163). If we take these factors into account, it may for instance help to explain the relative instability of many African rebel movements resting on Big Man/warlord logics.

There will inevitably be regions, or localities, where the idea of who, or what, a Big Man is will differ from the overarching framework. Thus, while we aim to employ the Big Man concept in case studies across the continent, one must expect that the definition given here will fit in some settings better than in others. Médard (1992) has explicitly used Sahlins' Big Man model in exploring African politics, pointing out how African Big Men convert economic resources into political authority (cf. Chapter 7 in this volume) and how state affairs become quintessentially personal (cf. Chapter 8 in this volume). However, other authors focusing on Africa use the term as a rather loose label and in a variety of ways. To give a few examples: in Burundian refugee camps in Tanzania, liminal experts or brokers who operate in the space in between refugees and humanitarian aid agencies such as UNHCR are referred to as Big Men by Simon Turner (2010: 86-7). Johan de Smedt employs the term when discussing election violence and vote manipulation in Kenya's 2007 elections. Highlighting the fact that 'local "big men" exercised authority by sharing out their wealth - the recipients of this redistribution, the poor, then "inevitably owed obedience"' (de Smedt 2009: 583) - he explains how British-created 'tribes' continue to function as political avenues for ethnic patronage that ties local Big Men to the 'ultimate Big Man', the president (ibid.). In his book Big Men, Small Boys and Politics in Ghana (1995), Paul Nugent situates Big Men of the political arena in open-ended hierarchical relations. 'The "big man" issues commands, normally from a seated position, while subordinates do the running,' states Nugent (ibid.: 3). A Big Man is primarily, but not only, a political figure associated with opulence. Bigness is in part measured in status symbols and the ability to fill that Big Man role according to social criteria. In Ghanaian politics, Big Men 'sought to win over potential voters by insinuating that some 
of this wealth would rub off on them - either directly (through patronage) or indirectly (because of the application of their business acumen to national affairs)' (ibid.: 5). Despite different usage of the term, Bigmanity can be said to hold a number of key characteristics:

1 Bigmanity is based on social relations. 'A big-man is one who can create and use social relations which give him leverage on others' production,' says Sahlins (1963: 292). Big Men transform social relations into strategic power and control (Médard 1992). Bigmanity forms loose social webs based on the ability to gather followers. In some settings this form of gathering is more important than economic wealth, access to land or formal political power. This has been called 'wealth in people' (Guyer 1993) or a rights-in-person complex (Kopytoff and Miers 1977), or has been linked with the notion of 'being for' someone (Bledsoe 1990; see also Utas 2008a).

2 Big Men do not generally control followers. Quite the opposite; it is in the interest of followers to maintain ties with a Big Man (and it is rarely just one) because Big Men provide economic possibilities as well as protection and social security. Bigmanity is far from mere wealth gathering. Big Men are not merely rational-choice wealth-generating positions; to maintain a Big Man position, one must extend solidarity within a moral framework. Gathering of power and its maintenance are built on forms of reciprocity, and if the Big Man does not distribute enough largesse he will eventually lose his supporters. Bigmanity is unfixed and multiple. Bigmanity is not a matter of inherited patron-client structures, but rather fluid and ever-changeable webs of relations. Some Big Men endure a lifetime at the centre of things while many others come and go. Followers may discard Big Men when they do not deliver. At the same time a follower is not loyal to just one Big Man, but typically enjoys different relationships with different Big Men.

3 Bigmanity is a response to a lack of formal structures. Typically, Big Men wield a great deal of social power in situations where there is a structural void. Big Man power should be seen as an alternative form of governance, where the national state doesn't reach, or where local forms of formal governance do not have sufficient sovereign powers. Formal structures are typically weakened during conflicts which thus give increased room for Bigmanity. Big Men networks may or may not involve the façades of the state. Big Men ought not to be seen as an opposing system to that of the state - quite the contrary. Politicians as well as civil servants use their positions within the state to engage business and cultivate relationships 'based on their role in tendering contracts, issuing licenses, and approving land use plans' (Simone 2004b: 81). The fewer functioning checks and balances there are, the more room there is for the Big Man to manoeuvre. 
position within social relations. It implies that a Big Man may well have his own Big Man. Furthermore, 'small' systems of Big Men and followers also occur at the grassroots level of a society (even the boy has his boy). There is a structural tension between the Big Man and 'the small boys', coming to the fore in studies such as Richards (1996) and Jackson (2004), where Big Men aim at controlling the production of their followers and this tension gives rise to the desire of underlings to slip the leash, as well as radicalizing discourses and in some cases sparking revolutionary engagements. Violent conflicts open up possibilities for underlings to contest power and climb the social ladder (Utas 2008a, 2009).

\section{Network}

Mark Duffield discusses war as a network enterprise (2002) using Manuel Castells' ideas of the new information society as a basis, when he defines the network enterprise as 'the generic institutional expression of the new global/ informational economy' (ibid.: 154). He draws conclusions about certain aspects of networks from Castells' The Rise of the Network Society (1996), seeing networks not as oligopolistic, but rather interconnected groups of decentralized components with significant autonomy making room for competition within shared strategies (Duffield 2002: 154). Networks are not primarily concerned with territorial control but aim at 'constructing flexible relations between sets of information-sharing companies in different institutional or spatial environments' (ibid.); thus such networks come to resemble business projects, as we shall see below. New information technologies have played a seminal role in the success of 'the network' in this broader sense. Somalia may be the prime case of a Castellsian war where a diaspora community is directly connected through new media and information flows to friends, family and business community within the war zone itself. Alongside information flows run intricate transfer networks of money, goods and people that in many ways sustain the war (Little 2003; Lindley 2009). However, all African wars do not look the same; the wars in Sierra Leone and Liberia, for instance, differed substantially from the Somali experience in that new media communication flows played much less of a role.

The idea of the networks often prompts associations of social threat. We tend to think of networks as illicit (see, e.g., Eilstrup-Sangiovanni and Jones 2008). Al-Qaeda is the contemporary example par excellence, with semiindependent cells and terrorist goals. Rhizomic networks with tacit underground derivations make these structures seem the opposite of 'up in the air' information networks, although information hubs and flows are today crucial for illicit activities to prosper. Other 'threatening networks' could be networks of curiously successful Japanese firms in 1980s and 1990s USA (as discussed in Podolny and Page 1998), but also Freemasonry across the world, or secret 
societies in, for instance, West Africa. Secret society networks such as the Poro in Liberia and Sierra Leone have been obsessively studied. Although the heyday of such study has passed, many have continued to fear the informal powers of societies based on secret networks. A few years ago, I met a UN police officer who was preoccupied with unmasking the members and informal activities of the secret male Poro of Nimba County in rural Liberia, certain that everything damaging that happened in the county had its origin within that secret realm. Elsewhere, examples of 'malevolent' networks that come to mind are drug cartels (see Chapter 6) and economic networks extracting resources in conflict areas (cf. Chapters 1 and 10).

Duffield's study of wars as network enterprises focuses on emerging global rather than local structures. Although the emphasis of this volume is on the latter, there are clear resemblances and also a profound connectedness between a local conflict and global networks, as most chapters in this volume demonstrate. By making Castells' information networks the starting point for his analysis, Duffield, however, implies that network society (and war) is something new, made possible only in and by the information age, but other researchers have at least since the 1950 s pointed out the importance of social networks. There is a rich history of network studies starting with Barnes' study of the Norwegian island parish Bremnes, published in 1954 (Barnes 1954). By the end of the 1950s and early 1960s, social anthropologists were anticipating great things from the study of social networks. Hopes were raised that network studies would enhance an understanding of social change (Kapferer 1973: 83). Clearly, the study of networks has since then experienced ups and downs, and researchers continue to consider networks important but hard to pin down with precision. Podolny and Page (1998) point towards a vogue of network studies in organizational economy in the 1990s, where they filled a theoretical void in explaining economic patterns that did not fit the classic duality of market and hierarchy.

Clyde Mitchell (1973; see also Mitchell 1974), in his overview of network studies within social anthropology, identifies Barnes as the first venturing beyond the classic understanding of kin and family networks when he described the social network as 'a set of personal relationships which interfused and crosscut the set of relationships in the industrial [work-related] and territorial [place-related] systems' (Mitchell 1973: 15). Mitchell points out that social class and neighbourhood are typical variables that influence the 'connectedness' of social networks. Such factors are, however, not straight determinants and typically networks cut across villages and across kin- and identity-based groups. Thus the network deviated from (in his words) 'traditional' social systems (ibid.: 17, 21). Although he posits a theoretical differentiation between the boundedness of a social group and the unboundedness of networks, in practice they are interconnected and not easily separated (ibid.: 20). 
Quoting Srinivas and Béteille (1964), Mitchell defines a social network as 'a set of concrete individuals who are members of diverse systems of enduring groups and categories' (Mitchell 1973: 21). Srinivas and Béteille look at the network from an actor-centred perspective. Bruce Kapferer, in his work on social networks in Zambia, proposes a similarly actor-centred approach: 'The concept network for my purpose refers to a set of points (individuals) defined in relation to an initial point (ego) and linked by lines (relationships) either directly or indirectly to this initial point of focus' (Kapferer 1973: 84). Mitchell argues that '[f] or a deeper understanding it is necessary not only to chart concrete networks of different individuals but to relate these different networks to one another, to draw up, so to say, a master chart, in a coherent and systematic manner' (Mitchell 1973: 22). But to study networks and relate them to each other is hard enough in a study localized to a neighbourhood (e.g. Kapferer (1973) and Epstein (1961)). The networks of conflict economies with which we are preoccupied in this volume are much wider, ranging over neighbourhoods and cities, into the rural, and over the national and transnational. They frequently, but not always, range into the clandestine, if not illicit. Most assuredly, it is not possible to draw up complete master charts of such complexity. It is a tough enough task to describe temporary nodes, Big Men and how they work and combine efforts for social, political and economic action in the form of joint projects. The very fluidity of conflict networks is an obstacle to any systematic study. Still, we must attempt a shift from 'the subjective network of the actor to the objective one of the observer' (Mitchell 1973: 22), maintaining a suitable degree of humility in taking on this challenge.

Returning to the practical/functional aspect, a network should be 'thought of as the actual set of links of all kinds among a set of individuals' (ibid.: 22). Graphically, the social relationships of individuals in networks are drawn as lines with individuals as connected points, but as Mitchell points out, this is not sufficient, as we need also to observe what kind of relationship every single line stands for (ibid.: 23) - is it a political tie, an economic relationship, or both? To add to the complexity, not all ties remain the same over time. Ultimately we must also identify the nodes/Big Men and take into account their multiple roles in addition to the plethora of links they maintain. Adrian Mayer (1966), for instance, studied 'action sets' in elections, tracing sets of offers of services that were exchanged for support during an election (Mitchell 1973: 25). Voters were connected to political candidates through expectations of patronage. Mayer observed thirty-eight links between a particular candidate and voters. Ten of them were kinship based, seven were economic links, four were caste based and the rest had other characteristics: 'the state, the wrestling club, trade union membership, occupational links, village links and so on'. Mitchell points out that Mayer's study involved three kinds of network: the exchange network, a communications network and a social network (ibid.: 25). 
This variety of network forms and functions is highly relevant to conflict networks (as perhaps becomes especially clear in Chapters 2, 3 and 5 in this volume). Furthermore, common interests and goals tend to incorporate certain norms and values that form the basis for a social network (ibid.: 32-3). Rules to play by are important in networks and formations of trust or control appear central for the network to function, but also present a built-in disadvantage compared to formalized enterprises or governance structures, as is obvious in post-conflict power-sharing agreements (see Chapter 8 in this volume).

Common values have become the focus of more recent research into networks of corporations and businesses. Podolny and Page, in their study of network organizations, speak about a network as a 'moral community' guided by joint ethics (Podolny and Page 1998: 61) where '[e]ach member of the network feels a sense of obligation to the other party or parties rather than a desire to take advantage of any trust that may have been established' (ibid.: $60)$. Walter Powell points out that, in network forms of resource allocation, individuals are more dependent on others (Powell 1990: 303) and that some forms of exchange are more social than others - 'that is, more dependent on relationships, mutual interests, and reputation - as well as less guided by a formal structure of authority' (ibid.: 300). These researchers contrast market and hierarchy, as per classic organization theory, but argue in addition for the network as a third mode of organization. Networks consist of reciprocal patterns of communications and exchange (ibid.: 295) with network shapes being based on 'lateral or horizontal patterns of exchange, interdependent flows of resources, and reciprocal lines of communication' (ibid.: 296). Networks can, then, be described as an 'intricate latticework of collaborative ventures with other firms, most of whom are ostensibly competitors' (ibid.: 301). From this strand of research, we can draw the notion of networks as complex organisms in free-market-like relations, which 'involve neither explicit criteria of the market, nor the familiar paternalism of the hierarchy' (ibid.: 303). Networks are thus not only horizontal, and patron-client relations are not just vertical. A combination of both gives Big Men networks. It is interesting to see how de Waal's concept of African countries as patrimonial marketplaces, as previously discussed, communicates neatly with these ideas.

'From a structural perspective every form of organization is a network, and market and hierarchy are simply two manifestations of the broader type,' state Podolny and Page (1998: 58). Market relations are not enduring but, rather, episodic and, conversely, hierarchies consist of relations that are enduring but by no means permanent (ibid.). From a governance perspective, a network form of organization is 'any collection of actors that pursue repeated, enduring exchange relations with one another and, at the same time, lack a legitimate organizational authority to arbitrate and resolve disputes that may arise during exchange' (ibid.). This fact caters for flexible network solutions 
allowing innovation and adaptation to new methods as 'network forms allow participating firms to learn new skills, gain legitimacy, improve economic performance and manage resource dependencies' (ibid.: 66). Flexibility and innovation are in particular key elements to understanding the success of both economic and social networks in times of conflict, as is clearly pointed out in most chapters of this volume. Below, I list factors that appear to be essential for our study of networks in conflicts. If we stay with the graphic idea of a network with nodes/Big Men and connecting lines between them representing ties of all kinds (economic, political, social and so on), then the points at which they cross each other are common projects, and this network exhibits a number of characteristics:

1 The success of a network project does not depend solely upon the number of Big Men involved but also on the degree of power that individual Big Men invest and the resources - including human resources/followers - they possess. Weight and density of a network are thus central to how efficient the outcome will be (Duffield 2002: 155; Kapferer 1973: 84), although it should be noted that '[a] potential network of relations is maintained that need not be activated right away but that exists in some immanent state for future mobilization when necessary' (Simone 2004b: 227).

2 Networks are unstable, changing and constantly adaptable. As such, social networks are in its double meanings nervous systems (Taussig 1992). Clandestinity of networks makes them efficient, flexible and adaptable to new functions, where new nodes/Big Men can be added while older ones can be subtracted with great ease. Furthermore, few formal, transparent mechanisms at either state or regional level can function without the support or authorization of informal networks and Big Men. Network logic is based on a spectral order of things, as Simone (2004b) puts it. Socio-economic networks are very much part of the daily cut-and-paste activities of the bricoleur (Lévi-Strauss 1966). '[A]ctors may assume one point of view or position within a local context, but take a very different position outside the locality' (Simone 2004b: 236), and Simone further notes that 'it is rare that any African urban resident is without some kind of external network that can be plied or mobilized in some way' (ibid.: 238).

3 Networks cut across social and economic groups as well as geographies (ibid.: 235) but still rest on common interests, although not necessarily the same goals. When Big Men from different backgrounds and with different capacities share the same goals (although not necessarily for the same reasons) - that is, have interest in the same project - then a network becomes strong. Networks do not need to have the same socio-cultural background, beyond the capacity to communicate. Rather, difference is an advantage for network operations because they can work across virtually any divides. 
At the same time, this fact makes them more vulnerable, fragile and less durable. It should be noted that network ties connecting actors from different areas and social backgrounds may counteract identity-based conflict as they draw strength from heterogeneity. Networks are not simply horizontal systems and Big Men hierarchies cannot simply be understood as vertical ties of patron-client relations but Big Man networks must be understood as intricate webs of power - accounts of 'African patrimonialism' frequently fail to show this.

4 As networks cut across social space it is only natural that criminal actors are involved as well. Some networks concentrate more on criminal activities than others (see Chapter 6 in this volume). However, in an efficient network it is often an advantage to involve criminal nodes, or at least players who are less morally concerned. The Jago and the Preman in Indonesia are good examples of actors taking a natural part in larger socio-economic networks (Schulte Nordholt 1991; Ryter 1998; Schulte Nordholt and van Till 1999), ${ }^{8}$ while politically and economically connected mafia organizations are wellknown examples of networks across the world (see, e.g., Blok 1972, 1974). Yet it is important to point out that although some Big Men are criminals, most are not. Conflict networks are far from only about illicit commodity extraction and trade, but also about providing security, development and peace initiatives. Networks are alternative governance structures in particular in settings where other forms of governance are weak. Big Men and networks are not the prototypical form of governance in Africa any more than elsewhere in the world. Network forms of governance are a response to certain organizational factors in present-day Africa. Big Men appear in structural voids of the state, skilfully combining network governance, social control and economic activities. In this volume, we point out that Big Men and networks play particularly prominent roles in war and conflict.

\section{Big Men and networks of governance in African conflicts}

African wars in the post-Cold War era have commonly been dubbed New Wars, after Mary Kaldor's influential book New and Old Wars: Organised violence in a global era (1999), although critical voices have been raised, questioning the validity of this old/new distinction (e.g. Kalyvas 2001; Chan 2011). De Waal points out that "[t]he term "new wars" utilized by Mary Kaldor describes conflicts in less governed countries, rather than truly new forms of conflict' (de Waal 2009: 101). And Duffield contends that what is in fact 'new' is the security terrain shaped by network war (2002: 153, 156). ${ }^{9}$ Network wars are rhizomatic, anti-institutional in character (ibid.: 161) and typically associated with shifts in social life (ibid.: 154). Instead of 'failures of modernity', Duffield, following Ulrich Beck (1992), proposes that we view these new network wars as an 'ambivalent and violent form of reflexive modernity' where '[w]ar as a reflexive 
and network enterprise does not follow the traditional state-based pattern of escalation, stalemate and decline' (Duffield 2002: 158).

Current networked wars in Africa involve not just national but hordes of external (African or non-African) actors. It is crucial to study networks of such actors in order to understand these wars. External actors, such as businessmen, peacekeepers and aid donors, function as Big Men and connect in one way or another to national and regional networks. This is more pronounced in countries marked by conflicts than those not. Conflict countries are in fact soaking up international capital, according to William Reno (in Ferguson 2006: 41). In 1994 and 1995, half of private capital inflows to Africa south of the Sahara (except for South Africa) went to four countries with weak states, and three with ongoing civil wars: Liberia, Sierra Leone, DRC and Nigeria (ibid.). War economies link local resources illegally or legally to global markets in a variety of ways (Duffield 2002: 157; cf. also Chapters 1, 4, 6 and 10 in this volume). Blood diamonds and other conflict minerals have received widespread attention, timber and foodstuffs less, although they are equally important. There are also flows of human resources in the form of conflict-related migrants as well as more directly conflict-related labourers, such as mercenary soldiers in the booming business of private security companies in, for instance, Iraq. ${ }^{10}$

Duffield notes that 'war economies, terrorist networks and criminal syndicates have increasingly become interconnected, not only among themselves, with legitimate businesses and established systems as well' (ibid.: 158). This is a central tenet of this book, yet we should be cautioned here by Reno's claim that many scholars conflate war and crime but tend to forget how peacetime politics may be even more conflated with crime than are the politics of war (Reno 2010: 128) and also keep in mind that conflict and post-conflict networks are not merely criminal, but also forms of alternative governance (as most chapters in this volume clearly point out). Yet fears persist that the illegal trade networks of wartime will jeopardize the fragile peace in several West African countries. Reno holds that drugs with a wholesale value of around $\$ 1.8$ billion pass through West Africa on a yearly basis. Profits of an estimated \$450 million end up in the pockets of traffickers, incomes that exceed the entire state budgets of several West African countries. Furthermore, an estimated ten million small arms circulate in West Africa (ibid.: 128-9). But organized crime is rife also in states that have not experienced direct civil war. For instance, in Nigeria, according to Nigeria's Economic and Financial Crimes Commission, the 'state is not even corruption. It's organized crime' (Watts 2008, cited in Reno 2010: 141). Reno correctly points out '[t]he irony ... that some of the actors who are held to be responsible for misdeeds in war and the exploitation of illicit commerce turn out to be best suited and most motivated to cater for the interests of young ex-combatants while those who participate most fully in postconflict reconstruction present the most risk of 
repeating patterns of behavior that are blamed for hindering the life prospects of young people' (ibid.: 145). This is a paradox to which I shall return in the concluding remarks of this introduction.

Few have done more for our understanding of the shadow side of African conflict networks than William Reno. However, some of the revelations of Carolyn Nordstrom are equally important and challenging, especially as her work on illicit war economies is poignantly global, beginning in African war zones, but ending up in the backyards of Europe and the USA. That there is a 'thin line between criminal traffic and government-inspired trade' (Castells 1998: 178, in Nordstrom 2007: 15) is something that Nordstrom's research makes intelligible, in Shadows of War (2004) and more so in Global Outlaws (2007). For the purposes of this book, I see the story of the Angolan 'governor' and his red tractors as particularly instructive, among a number of imperative examples of how social transaction, political power and economic wealth are interlaced and accumulated in the global shadows. The governor uses his political position and global connections with economic actors and the international aid business, involving local labour on close-to-slave contracts, INGO food-for-work arrangements and hordes of internally displaced peoples (IDPs); INGO tools, including heavy equipment such as tractors; and European air carriers - all to accumulate extreme personal wealth (ibid.: 27-35). What Nordstrom in particular underlines is how illicit Big Men play important roles in most networks, whether in conflict zones or well beyond. Many socio-economic networks list at least some criminal elements. These actors are often Big Men in their own right. Schulte Nordholt, for instance, as briefly mentioned above, has looked at the semi-criminal character of the Jago on Java, a figure that turned out to play a significant role in colonial Indonesia. He states that 'The jago was not a bandit ... He did not stand outside society but instead formed a crucial link with the political system. There was no transition from crime to rebellion, because the jago was part of the colonial power structure' (Schulte Nordholt and van Till 1999: 68). Borrowing from Anton Blok's historical work on the Sicilian Mafia (Blok 1972, 1974), Schulte Nordholdt points out that Jago figures gain importance in 'a process of unfinished state development in which local order breaks down and new groupings set themselves up violently as political entrepreneurs' (Schulte Nordholdt 1991: 89). What I want to stress with this comparison, albeit from an entirely different geographical context, is that criminal elements are important as components within political networks around the state as well as in direct contestation with the state. Jagos are clearly Big Men in their own right and have the capacity to grow considerably in times of socio-political unrest. ${ }^{11}$

The moral ambivalence of Big Men, the porosity and fluidity between legal and illegal, crime and politics, is pinpointed in several of the chapters in this volume. The following example is particularly connected to Anders' study (Chapter 7): Gus Kouwenhoven, a Dutch national and long-time resident of 
Liberia, personifies the criminal Big Man of African conflict networks in many ways. After committing a variety of crimes in Europe and the USA, he fled justice and headed to West Africa. There, by pretending to be an international businessman, he conned his way into leasing Hotel Africa, the largest Monrovia hotel, from Liberian president Samuel Doe in the mid-1980s. From this position, he worked his way into the centre of the political economy in pre-war Liberia. When the war started, he smoothly changed sides and became a close ally of Charles Taylor, rebel leader and later president. Under Taylor's presidency, Kouwenhoven remained a key player, brokering a deal, among many others, with the Oriental Timber Company, which subsequently exported large quantities of hardwood from Liberia's virgin rainforest. Kouwenhoven allegedly also brokered arms deals for Taylor despite an international embargo. While clearly on the radar for international crimes, he simultaneously continued to run Hotel Africa and a whole complex of villas in its vicinity. During much of this time, the hotel and villas were rented by the United Nations for a presumed fortune. Kouwenhoven's broad international network, along with his standing as a Liberian Big Man, was essential to his success. In perfect keeping with the rules for a local Big Man, he was not just known for being a businessman. At the time I was living in the country, many Monrovians told me that Kouwenhoven helped people by paying children's school fees and making other redistributive efforts. Together with other key players around Charles Taylor, he was placed under a UN travel ban, but apparently still managed to travel to Europe on a number of occasions. After the fall of Charles Taylor, he could no longer reside in Liberia and was finally arrested by Dutch police in the town of his birth, Rotterdam, in 2005. In June 2006 he was sentenced to eight years in jail for arms smuggling. The court, however, did not find him guilty of war crimes despite his role in Liberia during the Taylor years. Were it not for well-connected Big Men criminals such as Kouwenhoven, war endeavours like Taylor's would make limited headway.

Informal wartime networks consist of a multitude of actors: politicians and political parties, military, finance, NGOs, national and international actors, religious leaders, businessmen, warlords and trade union leaders. As I have pointed out above, network analysis is taking us beyond simple identity-based categorizations of ethnicity, regional attachments and religion as key factors behind conflict. Many chapters in this book propose alternative logics to such categories, as well as demonstrating other driving forces (see, e.g., Chapters 4 and 9). It is clear that informal networks characteristically transgress the political landscape and, rather than pitching individuals against each other, exist alongside politicized identities. Yet conflicts rarely unfold owing to the existence of informal networks. Indeed, at certain times informal networks do manipulate differences, but from the viewpoint of economic logic this is seldom a choice preferred by conflict-based Big Men. ${ }^{12}$ 
Networks themselves are social creations, guided by common cultural codes, as noted above. Duffield points out how, during conflicts, '[e]ach of the components and nodes in a networked system such as those associated with reflexive forms of resistance and organized violence, are sites where new identities emerge, roles are reinvented, and novel forms of social legitimacy become established' (Duffield 2002: 160). Networks are reshaped by violence, but are also actively reshaping social space itself. Big Men who at the onset of a violent conflict may be marginal will move to the centre of networks owing to their knowledge of violence and access to potential soldiers and arms. Often, illicit Big Men take positions in networks where they previously played marginal roles. Once peace is restored, the network may morph back into its previous shape, or previously marginal Big Men may remain central, but aiming at more peaceful roles (although at times failing to do so, as discussed in Chapter 7 in this volume). Wars and conflict have at times made marginal Big Men even bigger in the post-war period. Typically, they will rise in power in political networks (cf. Chapters 2 and 5), but also in business networks where control over people is crucial (cf. Chapters 4 and 6).

De Waal, in his study of conflicts as marketplaces, states that 'political life can be described as an auction of loyalties in which provincial elites seek to extract from one or other metropolitan centre the best price for their allegiance' (de Waal 2009: 103). In fact, 'the marketplace of loyalties also operates at a lower level, whereby provincial elites secure support, including votes and guns, of their constituents in return for money, jobs and licenses to trade or pillage ... a similar market also operates within each metropolitan elite' (ibid.). Big Men, or what he calls provincial elite members, have in their turn their own Big Men, or metropolitan elites, with whom they bargain over loyalty compensated for by votes, money or violence (ibid.: 103-4; cf. also Chapter 8 of this volume). De Waal goes on to show how political bargains between metropolitan elites and provincial elites are quite short-term - often covering only two to three years - and then need to be renegotiated (ibid.: 104), stressing how network systems are nervously changing and flexible. In conflicts, changes appear even more rapidly: loyalties change overnight and rebel factions merge and fall apart (see Chapter 3). Big Men within the rebel armies, the commanders, take their men and join other factions, while foot soldiers change Big Man, rather than making individual political or identity-based moves (Utas 2008a; cf. also Chapter 9 in this volume); on the other hand violent conflict is a landscape of opportunity for subaltern Big Men motivated by individual socio-economic mobility (Utas 2009; cf. also Chapters 3 and 5 in this volume).

\section{Big Men, networks and post-conflict}

There is little doubt that liaisons between Big Men on different levels and in different settings within a conflict zone, but also outside in a broader 
warscape (Nordstrom 1997), have implications for the possible success of peace negotiations (as pointed out in Chapter 8 of this volume) and the sustainability of peace accords. Peace accords, de Waal states, 'will work only if the formal negotiations over constitutional provisions and power-sharing takes place in support of a patrimonial buy-in' (de Waal 2009: 108). ${ }^{13}$ According to the logic of the marketplace, failing to do so implies that agreements end up as simple 'bargains that stick for as long as it suits the interest of both parties' (ibid.). As such provisions are chiefly viewed as pacts between government and provincial elites, hinged on security and patronage, there is actually a risk that they may increase violence. In addition, other Big Men, such as military and rebel commanders, have an equal interest in the possible end points of conflicts and so their informal investments and interests must also be taken into account. Moreover, it is imperative to emphasize that warfare is in some places the typical arena for Big Man politics (Utas 2008a, 2009). Warlords and other Big Men regularly enter not just conflicts, but also peace processes, as a result of personal socio-economic opportunities and prospects for personal advantage. Frequently such actors are aware of risks for their own safety and prosperity in the post-conflict setting (cf. Chapters 7, 8 and 10 in this volume).

As previously pointed out, conflict networks, in the eyes of the international emergency aid/post-war recovery industry, are seen only as a danger to the stability in war-ridden African states. Such observers fail to understand that these networks are far from simply criminal and a danger to stability but are, rather, extensions and reconfigurations of informally governing networks working in peacetime as well. Networks cannot simply be destroyed as they are multifaceted institutions governing, protecting and supporting most aspects of life in these countries. In many cases they are the very structures on which the government itself is resting. If Big Men are structurally as important as authors in this volume suggests, does this fact justify the efforts of the international justice system to indict war criminals? Are the International Criminal Court's indictments of President Bashir in Sudan and of a number of rebel and militia leaders in the DRC, or the Special Court for Sierra Leone's indictment of Charles Taylor from neighbouring Liberia, efficient methods for change and peace, or merely justice to victims only? (Further discussed in Chapter 7 of this volume.) Here, we need to reflect on what we know about the functioning of networks of Big Men, who partly combine efforts and partly compete over power. If a central Big Man disappears another Big Man will move into his/her position. In Liberia the removal of Charles Taylor, and his forced absence from the scene as the 'Biggest Man', did not lead to the death of his network. His loss of might was military, rather than diplomatic or legal, and occurred on the Liberian battlefield. He left the country owing to the military victory of the LURD and MODEL rebel movements, not as a consequence of his indictment by the Special Court for Sierra Leone. Other Big Men around Taylor maintained 
much of their powers after his removal; in fact, many of the financial Big Men, and to a lesser extent the political ones, moved their interests from around Taylor and later re-emerged as supporters and partially financial backers of the new Biggest (Wo)man, Ellen Johnson Sirleaf, elected president and cherished by the entire international community. In many ways, it could be argued that Taylor and Johnson Sirleaf had throughout the political commotion (and war) been part of the same network, although in competition (Utas 2008b). When Taylor lost out militarily, Big Men loyal to him regrouped around Johnson Sirleaf. 'Like a living organism, if you change its environment, in order to survive it will mutate - even to the extent of becoming a different life-form altogether,' states Duffield (2002: 158). And thus many Big Men maintain their grasp on socio-economic and political power, albeit by less violent means.

William Reno raises doubt as to whether the destruction of wartime militia networks is a viable path to a more stable and peaceful future in West Africa - and, by extension, in much of Africa - pointing out that instead of leading to chronic instability, violent commercial networks are seen playing important roles in creating new versions of sustainable order in communities and in creating new commercial opportunities that persist after a war' (2010: 129). ${ }^{14}$ When politics is an extension of business and the interests of Big Men dominate state structures, then 'predation and plunder' may in fact contribute to 'new sustainable political economies' (ibid.: 130). But in places such as Liberia and Sierra Leone, Reno argues, the old local elites which have been restored to power in the aftermath of the civil wars are more corrupt, although less dependent on outright violent methods, and actually closer to the organizational logic of drug traffickers in Guinea-Bissau or corrupt civil servants in Nigeria than are wartime leaders and members of rebel groups in Liberia and Sierra Leone (ibid.: 131, 136). Indeed, state corruption in non-conflict countries is not random corruption, but in many cases the way government works; it is not incidental, but structural. Rebuilding centralized bureaucratic hierarchies

... does not necessary replace the logic of patronage-based rule in West Africa.

Instead, these state agencies risk institutionalizing such relations in new form. If new hybrid forms of formal institutions, patronage politics, and commerce result in a greater level of local exploitation and illicit international transactions, then it may be better to de-emphasize the construction of European style state administrations in postconflict West Africa and to work more intensively to assist what already works to varying degrees for people on the ground. (Ibid.: 132)

Many wartime militia networks do survive in post-war environments (and it is rather obvious, from discussions here, that they will) 'as commercial organizations, as community based NGOs, and in quasi administrative roles, 
depending on their positioning vis-à-vis broader developments within their country's political situation' (ibid.: 135). Such networks clearly demonstrate capacities in the post-war arena (cf. Chapters 2, 4 and 9 in this volume). If they are closer to the grass roots, ought they not to be supported instead of destroyed? asks Reno. 'Uncritical top-down approaches toward the process of restoration risk restoring centralized patronage networks that control less powerful people's economic prospects and diminish their chances to influence their fates through their own decisions' (ibid.: 141). De Waal has similar thoughts regarding peace negotiations: 'The logic of the political marketplace means that an internationally guaranteed peace agreement may actually be less durable than a purely domestic one, not more' (2009: 109). Both Reno and de Waal highlight the need both to understand and to allow the local/ domestic when studying and working with African conflicts; this, I would argue, is central to all chapters in this book.

\section{The chapters}

This volume is divided into two sections, one with country studies (Chapters 1-5) and one with thematically comparing chapters (6-10). The book is based on primary field research conducted by the authors themselves and has a multidisciplinary approach, combining scholars of political science, peace and conflict studies, political sociology, law and social anthropology.

In Chapter 1 Koen Vlassenroot and Sandrine Perrot scrutinize the semiprivatized military-economic networks that controlled the borderlands of DRC in the second Congolese war (1998-2003). Looking beyond criminalized descriptions that have been commonplace in UN reports, they focus on a trans-border military-commercial nexus tying the Ugandan military elite, with close connections to the Ugandan government, to the Congolese war, leading to refigurations of local regulation, power and control. Big Men within the Ugandan army used their military positions and great entrepreneurial skills to control both populations and resources in DRC. Two examples are very illustrative of this military entrepreneurialism. One is the case of Salim Saleh, Ugandan president Museveni's brother, who together with his wife and Museveni's son, Muhoozi Kainerugabe, developed a strategy of resource accumulation based on endless diversification of activities and the mixing of civilian and military businesses, charity, corruption and regional trading operations. Another example is General James Kazini, who initially led the operations of the Ugandan army in the DRC. Kazini evolved into a key actor in Congo's war economy, for which he constantly manipulated local actors and networks. The chapter by Vlassenroot and Perrot also challenges the argument that Big Men operate at the margins of the state and represent alternative power structures. Rather than weakening the Ugandan state, Ugandan military entrepreneurship and the semi-informalization of security structures created 
additional opportunities for regime consolidation. This brings the authors to the conclusion that there is a paradox between the constant undermining of state authority by parallel networks and the contribution of the same forces to the viability of the Ugandan state.

In Chapter 2 Maya Mynster Christensen focuses on events in the aftermath of the ten-year civil war in Sierra Leone. Here several former military commanders of both national army and rebel forces have in democratic processes carved out political space for themselves. Christensen is presenting a case study from a geographically remote area of Sierra Leone bordering Liberia and Guinea, where Tom Nyuma, a well-known 'warlord' in the civil war, was appointed chairman of the district council in Kailahun district after the national elections in 2007. The chapter shows how he has made shrewd use of his networks of ex-combatants, many of whom do not originate from the area, and thereby established himself as a prominent political and socio-economic Big Man. Nyuma is thus using both informal networks for his formal political ambitions and his formal political position for informal socio-economic profit. In classic Big Man fashion he is promoting his followers, and Christensen shows how junior commanders under his wing in the civil war make use of the space created by him to establish themselves as junior Big Men with both economic and political aspirations, most commonly with an aim not just to control local politics but to gain future positions in the Sierra Leonean capital Freetown.

In Chapter 3 Karel Arnaut deals with the proliferation of militias in the recent conflict in Côte d'Ivoire (2002-11). By placing specific emphasis on subaltern mobility of youngsters in urban Abidjan, he guides us through the waxing and waning of a myriad of militias. The latter are largely shaped by juvenile networking and vested in the Nouchi street culture of Abidjan, but also utilized by and closely connected to political and military Big Men in the country. The author is particularly interested in the youth militias' relationship with the corps habillés - army, police, etc. - that militia youth first and foremost relates to as support units, boosting its crippled capacity, but also aiming at integration into it as a major step towards social maturity and stability. Looking deeper into the dynamics of militia formation as impersonation of corps habillés, or, stated otherwise, as apprenticeship without real chances of full incorporation into the military, Arnaut scrutinizes the mutual complicity as well as the structural inequality of the two fellow armed forces in both war and post-war (or pre-peace, as he calls it) topographies. Arnaut is offering two key examples of militia Big Men and their manoeuvring of the fragile political environment of Abidjan during the reign of Laurent Gbagbo: that of the late Ato Belly and 'Marcus Garvey'. Both are young men who rose to a certain prominence during the past decade of conflict but in the end were not capable of transcending their subaltern position. The case of Ato Belly is that of a militia leader (who attained the rank of 'general' and was camp 
commander of two important militia barracks) whose success largely resides in the way he engages in building and managing his ' $g b o ̂ h i$ ' - the Nouchi label for 'gang': the kind of transient and yet socially consequential network that has become prototypical of urban juvenile life in Côte d'Ivoire during the last decade. Above all, the story of 'General' Ato shows how during that period the militarized gbôhi featured in larger constellations of patronage and political-military Bigmanity in Côte d'Ivoire. This also applies to the case of the militia member and gbôhi leader of lesser weight whose nom de guerre and nom de plume is 'Marcus Garvey'. In his autobiographical writings 'Marcus Garvey' reveals the intricacies of militia activity as the impersonation of corps habillés. As such, Garvey instantiates the militia membership of thousands of Ivoirian youths as a vital tactic of subaltern social mobility.

With case studies from post-war Liberia, Mariam Persson, in Chapter 4, shows how former commanders and soldiers from different rebel factions are carving out occupational niches in informal security and business sectors, by reutilizing chains of command and rebel networks maintained from the war years. Political Big Men, she points out, have gone a long way, not to demobilize and reintegrate, but rather to maintain such structures as means of power and security in an uncertain post-war terrain. Where the formal state has limited control, informal actors - although far from not being connected to Big Men within the state - become significant players. In the first part of the chapter Persson describes a vigilante group in Lofa County, where the leader is best portrayed as a local Big Man, connecting to more powerful people, but at the same time catering for and controlling groups of ex-combatants from within the Liberians United for Reconciliation and Democracy (LURD) rebel group. The Big Man's preference for including ex-combatants is due to the fact that they are already organized according to a military logic, and 'feared' in the local community. The second part of the chapter concerns the informal governance of one of the larger rubber plantations in the country. After the fall of Charles Taylor's government in 2003, LURD commanders took control of the plantation in a bid to maintain economic opportunities. LURD commander General X established himself as a Big Man in the area with control over business, with approximately five thousand ex-combatants as rubber tappers, as well as over socio-political life on and around the plantation. General $\mathrm{X}$ is a good example of the hybrid breed of a post-war Big Man successful in such a setting, where he commands and controls people beneath him, but is mandated his position by Bigger Men from within the political elite. In the case of General $\mathrm{X}$ these Bigger Men were Boakai Sirleaf, deputy minister of agriculture, and a relative of the Liberian president, and not least Fombah Sirleaf, director of the National Security Agency and stepson of the president, clearly pointing out that Liberian Big Man politics is a combination of political might, economic 
interest and violent control administrated through far- and deep-ranging informal networks criss-crossing geographic and social terrains.

Morten Bøås, in Chapter 5 , takes us to northern Mali, where from a historical perspective he scrutinizes the 2006 Tuareg rebellion. He shows how emerging illicit trade, smuggling of contraband cigarettes, emerging drugs trade and trafficking of people destined for Europe have created not only new regional networks, but also novel types of Big Men contesting local power. In previous Tuareg rebellions the Malian state has managed to co-opt old elites by involving them in state bureaucracy. Rebel leaders and key commanders saw both armed resistance, often using the rhetoric of fighting for an independent Tuareg nation, and cooperation with the Malian state as means to maintain local control.

Decentralization efforts after the second Tuareg rebellion, which took place between 1990 and 1996, however, created resources to organize new networks around Big Men controlling political constituencies and the extraction of resources, the building of fresh 'castles in the sand', to paraphrase the title of Bøås' chapter. Yet when peace dividends failed to materialize, Big Men, such as Ibrahim Ag Banhage in the Kidal district, with a combination of political will and personal ambitions, fought their way into the local political scene. A new feature was that these Big Men did not come from noble or royal lineages, and thus contested long-standing power in the region. The May 2006 rebellion was made possible in part by local discontent and in part by the aspirations of these new Big Men. Much is in flux in northern Mali, and Bøås states that it is the combination of Malian politics played out on the local scene and a re-emergence of the importance of old trade routes into Algeria (now chiefly with illicit goods, new regional networks with, for instance, al-Qaeda in the Land of Maghreb (AQIM) - although he is downplaying connections with al-Qaeda - and the Niger Justice Movement (MNJ)) which accounts for the emergence of these new Big Men.

Henrik Vigh's Chapter 6 is centred on local political consequences of international trade in illicit drugs. Political power and large-scale drugs smuggling have become intimately intertwined in many West Africa coastal states, now by some called the cocaine coast. Vigh's material is, however, from the most gravely affected country, Guinea-Bissau, a country that has been dubbed Africa's first 'narco state'. With a focus on cocaine connections, Vigh argues that global networks have particularly targeted the country owing to the crisis of the Guinea-Bissauian state, which has made it a perfect drug hub where illicit goods and smuggling routes can be protected, but not interfered with. The cocaine trade is maintained through networks around Big Men that in many instances first rose to prominence during the struggle for independence and subsequently during the civil war that began in 1998. Vigh pinpoints how the homi garandi, the local Creole term for Big Man, lent their political offices 
and networks to Colombian cocaine cartels, creating a booming business for the few, yet still a forceful network economy which many citizens are forced to relate to. It is a well-known secret that the former president, Nino Vieira, was, up until his murder, the Biggest Man in the cocaine trade. However, the decapitation of Vieira and several other drug kingpins hardly affected the business. Vigh is highlighting how both armed factions during the civil war and drug networks are loosely ordered and based on transaction rather than issues of principle (quoting Adrian Meyer's work on quasi-groups). Reordering within Big Man networks is part of their nature, and when one Big Man passes another slips into his shoes, yet if the basis for existence changes a whole network may cease to function, although in the case Vigh considers the cocaine economy maintains its continuity.

In Chapter 7 Gerhard Anders examines to what extent the advent of international criminal justice and the criminalization of the African modes of warfare it entailed affected politics in Sierra Leone and Liberia. He describes how former leaders and commanders of armed factions attempted to convert their wartime exploits into social status, economic wealth and political influence. The period between 1999 and 2003 was characterized by intense, often violent, political conflicts as military and economic Big Men repositioned themselves after the end of the war in Sierra Leone. The Special Court for Sierra Leone, an international ad hoc tribunal established in 2002 to hold accountable those bearing greatest responsibility for war crimes committed in Sierra Leone, played an important role in these domestic power struggles both in Sierra Leone and Liberia by preventing Sam Hinga Norman, former militia leader and Sierra Leone's minister of internal affairs at the time of his arrest in 2003, and Charles Taylor, former rebel leader and Liberian president between 1997 and 2003, from further pursuing their political careers. In court, both men tried to adapt to the requirements of legal fact-finding, but while Taylor performed extremely well in the witness stand, Norman failed to conduct his own defence. This shows how difficult it is to perform Bigmanity in the arena of an international war crimes trial. Anders' analysis traces the complex interplay of external and internal forces shaping contemporary African Big Man politics in the shadow of international criminal law's growing influence.

Ilmari Käihkö's Chapter 8 focuses on power-sharing and informal governance in conflicts around the African continent, ranging from full-scale wars to more limited forms of violent conflict. Käihkö's chapter starts off with a comprehensive discussion of Big Men and networks in relation to state power and political opposition in contemporary Africa - in some ways fleshing out points that I have only hinted at in this introduction. In the main body of his chapter the author observes that a major problem with the literature on power-sharing and co-option is that it seldom takes informal structures into account, but maintains a simple focus on the political party, the rebel group 
or militia, without observing that in most African countries these are rarely managed by a centralized administration, or have a single political agenda, but are rather fractured and made up by groups, or often individual Big Men with diverse and far from formal motives and agendas. On political parties, Käihkö notes that in reality they are often networks built around Big Men, constituting little more than façades for individually based interests. The same goes for many military movements and rebel factions on the continent, he further argues. As much of the real politics happens far from the formal façades, a deeper understanding of the informal realities of local contexts becomes of utmost importance. Käihkö concludes that a better understanding of contemporary African political realities can be gained only by combining the formal and informal perspectives, and therefore ending the strict categorization of politics into formal and informal.

Anders Themnér, in Chapter 9, points out that long after armed groups have been disarmed and demobilized, informal military networks continue to be a reality for many war-torn African societies. Often these structures are upheld by Big Men who see them as assets in their political and economic struggles with other elites. For Big Men it is especially important to gain access to excombatants. Accustomed to taking orders and possessing military skills, former fighters can be used for any number of socio-economic and political purposes, including warfare. For this reason, informal military networks constitute a significant challenge when building sustainable peace. However, in order to address the threat posed by such structures, it is necessary to acknowledge the role played by a post-conflict actor that is often forgotten - former mid-level commanders (MiLCs). As gatekeepers into ex-combatant communities, they possess a near-monopoly on interaction between Big Men and ex-fighters. Post-war elites are therefore often obliged to enlist ex-MiLCs as intermediaries in order to represent them in their dealings with former combatants. For this reason, any peace-building efforts failing to take ex-MiLCs into consideration run the risk of sowing the seeds of new violence.

Ruben de Koning, in Chapter 10, deals with the uses, or abuses, of natural resources in African conflict zones. By presenting examples from recent conflicts in Central and West Africa, the author starts with a discussion on so-called conflict resources and how Big Men with business, military and political backgrounds in times of conflict operate through controlling and administrating resources. He points towards a clear continuity in governance of resources over pre-war, war and post-war times, whereby rebel leaders in the conflicts often had direct stakes in the pre-war state, or were part of resource-full networks connected to pre-war governing structures. In other words, in most cases conflict resources are controlled by the same socio-economic Big Men as before the outbreak of civil war. De Koning is using DRC as an in-depth case, showing a variety of Big Men and networks set up around the management of 
conflict resources, with military commanders becoming informal governors, tax officials or mine guardians, and where Big Businessmen create militias, if not themselves transforming into rebel leaders. In the case of North Kivu he points out that a trading elite, together with local civil groups, managed to sideline rebels by creating its own militia, the Mai Mai, and thus maintained its grip over prosperous business and a level of socio-political leverage. On the other hand he also shows how in Kivu and elsewhere in the eastern DRC, networks headed by military Big Men control resources through taxation of mines and/or transport of minerals - for instance, the 85th brigade of the FARDC, the reformed national army, is believed to have levied informal taxes to the tune of US\$350,000 monthly from a single mine in 2007. The brigade did not just function as tax collectors controlling through violent means, but also to some extent protected civilians and helped settle local conflicts. De Koning also gives examples of how, in the process of army reform, through the inclusive brassage procedure, military Big Men refused, or delayed, the movement of their troops to new designated regions on the ground that they would lose control over resource rewards in strategic areas, a fact that has been a serious problem for successful army reform in the country. A final case of particular interest to this volume is how the Forces démocratiques de libération du Rwanda (FDLR) have not just been collecting revenues but have also given credits for commercial activities to actors both within and outside the FDLR, a typical Big Man form of redistribution.

\section{Notes}

1 The African continent is huge;

Africa cannot be explained in a single and comprehensive way as differences abound when it comes to economy, politics or sociology. By focusing broadly on the continent of Africa in this book, we are not arguing for Africa as a cultural region (it is not a 'culturology of African politics', in James Ferguson's phrase (2006)), nor for Africa as the result of a singular history.

2 Many writers have, justifiably, questioned the use of formal/informal distinctions, especially from an economic vantage point (Meagher 2010; MacGaffey 1991; MacGaffay et al. 2000; Hansen and Vaa 2004; Lourenço-Lindell 2010), but for the sake of simplicity we use 'formal' in this book to mean state-governed or state-controlled, and 'informal' for what is governed by other institutions, or partly ungoverned. Simone points out that, rather than a coherent category, the 'so-called informal sector is a kind of umbrella for a multitude of "stories"' (Simone 2004b: 24).

3 Big Man is not a gendered concept; despite the gender specificity of the term, women can also be Big Men.

4 Very much in line with what Hardt and Negri call the (new) Empire (2001).

5 Here we have what Christian Lund describes as the twilight institutions at work (2006).

6 Certainly also dependent on other structural conditions, but entering into more detail is beyond the scope of this book.

7 My emphasis. See critique by, for instance, Mkandawire (2002: 184); Erdmann and Engel (2006); and Olukoshi (2001, 2005). The latter has been one of the most vociferous critics of neopatrimonial explanation. He points out how neo-patrimonialism in itself becomes a catch-all paradigm that obstructs a wide 
diversity of explanations needed to understand African societies (Olukoshi, keynote speech, Uppsala, 28 October 2010).

8 See below for an extended discussion on the Jago and Preman in relation to criminal actors in conflict areas.

9 It is also worth pointing out that for some individuals war is a direct entry point to modernity (Utas 2008a).

10 On former Sierra Leone soldiers in Iraq, see, for example, Christensen and Utas (2008) and Utas (2010).

11 Loren Ryter shows the continuity of the Jago in the more recent Indonesian Preman (Ryter 1998).

12 On the other hand, it may be a method used by international businessmen and conglomerates forming part of conflict networks in a particular country or region.

13 There is still no guarantee that it will work.

14 Reno is describing how similar kinds of violent structures were a large part of the creation of European states, referring to the work of Charles Tilly (1992).

\section{References}

Abdulsamed, F. (2011) Somali Investment in Kenya, Chatham House Briefing Paper, Africa Programme, March.

Andersen, L., B. Møller and F. Stepputat (2007) Fragile States and Insecure People? Violence, security, and statehood in the twenty-first century, New York: Palgrave Macmillan.

Barnes, J. A. (1954) 'Class and committees in a Norwegian island parish', Human Relations, pp. 39-58.

Bayart, J.-F. (1993) The State in Africa: The politics of the belly, London and New York: Longman.

Bayart, J.-F., S. Ellis and B. Hibou (1999) The Criminalization of the State in Africa, Bloomington: Indiana University Press.

Beck, U. (1992) Risk Society: Towards a new modernity, London: Sage.

Biró, D. (2007) 'The (un)bearable lightness of ... violence: warlordism as an alternative form of governance in the
"Westphalian periphery"?', in T. Debiel and D. Lambach (eds), INEF Report 89, Duisburg/Essen: INEF.

Bledsoe, C. (1990) “'No success without struggle": social mobility and hardship for foster children in Sierra Leone', Man, 25: 70-88.

Blok, A. (1972) 'The peasant and the brigand: social banditry reconsidered', Comparative Studies in Society and History, 14: 494-503.

- (1974) The Mafia of a Sicilian village, 1860-1960; a study of violent peasant entrepeneurs, Oxford: Blackwell.

Bøås, M. and K. C. Dunn (2007) African Guerrillas: Raging against the machine, Boulder, CO: Lynne Rienner.

Bratton, M. and N. Van de Walle (1997) Democratic Experiments in Africa: Regime transitions in comparative perspective, Cambridge: Cambridge University Press.

Castells, M. (1996) The Rise of the Network Society. The information age: economy, society and culture, Malden, MA: Blackwell.

Chabal, P. and and J.-P. Daloz (1999) Africa Works: Disorder as political instrument, London/Oxford/Bloomington: International African Institute in association with James Currey and Indiana University Press.

Chan, S. (2011) 'On the uselessness of new wars theory: lessons from African conflicts', in C. Sylvester (ed.), Experiencing War, London: Routledge.

Christensen, M. M. and M. Utas (2008) 'Mercenaries of democracy: the "politricks" of remobilized combatants in the 2007 general elections, Sierra Leone', African Affairs, 107(429): 515-39.

Clapham, C. (1998) African Guerrillas, Oxford: James Currey.

De Smedt, J. (2009) '“No Raila, no peace!” Big Man politics and election violence at the Kibera grassroots', African Affairs, 108: 581-98.

De Waal, A. (2009) 'Mission without end? Peacekeeping in the African marketplace', International Affairs, 85: 99-113. Duffield, M. (2001) Global Governance and 
the New Wars: The merging of development and security, London: Zed Books.

- (2002) 'War as a network enterprise: the new security terrain and its implications', Journal for Cultural Research, 6: $153^{-65}$.

Eilstrup-Sangiovanni, M. and C. Jones (2008) 'Assessing the dangers of illicit networks: why al-Qaida may be less threatening than many think', International Security, 33: 7-44.

Epstein, A. L. (1961) 'The network and urban social organization', RhodesLivingstone Institute Journal, pp. 29-62.

Erdmann, G. and U. Engel (2006) 'Neopatrimonialism revisited - beyond a catch-all concept', Giga (German Institute of Global and Area Studies) Working Papers no. 16, pp. 1-38.

Fanthorpe, R. (2001) 'Neither citizen nor subject? "Lumpen" agency and the legacy of native administration in $\mathrm{Si}$ erra Leone', African Affairs, 100: 363-86.

Ferguson, J. (2006) Global Shadows: Africa in the neoliberal world order, Durham, NC: Duke University Press.

Godelier, M. (1986) The Making of Great Men: Male domination and power among the New Guinea Baruya, Cambridge: Cambridge University Press.

Godelier, M. and M. Strathern (eds) (1991) Big Men and Great Men: Personifications of power in Melanesia, Cambridge: Cambridge University Press.

Goffman, E. (1959) The Presentation of Self in Everyday Life, Garden City, NY: Doubleday.

Guyer, J. I. (1993) 'Wealth in people and self-realization in Equatorial Africa', Man, 28: 243-65.

Hansen, K. T. and M. Vaa (2004) Reconsidering Informality: Perspectives from urban Africa, Uppsala: Nordiska Afrikainstitutet.

Hansen, T. B. and F. Stepputat (eds) (2005) Sovereign Bodies: Citizens, migrants, and states in the postcolonial world, Princeton, NJ: Princeton University Press.

Hardt, M. and A. Negri (2001) Empire, Cambridge, MA: Harvard University Press.
Herzfeld, M. (1997) Cultural Intimacy: Social poetics in the nation-state, New York: Routledge.

Huntington, S. P. (1997) The Clash of Civilizations and the Remaking of World Order, New York: Touchstone.

Jackson, M. (2004) In Sierra Leone, Durham, NC: Duke University Press.

Kaldor, M. (1999) New and Old Wars: Organized violence in a global era, Stanford, CA: Stanford University Press.

Kalyvas, S. N. (2001) "New" and "old" civil wars a valid distinction?', World Politics, 54: 99-118.

Kapferer, B. (1973) 'Social network and conjugal role in urban Zambia: towards a reformulation of the Bott hypothesis', in J. Boissevain and C. Mitchell (eds), Network Analysis: studies in human interaction, The Hague: Mouton.

Kopytoff, I. and S. Miers (1977) 'African "slavery" as an institution of marginality', in I. Kopytoff and S. Miers (eds), Slavery in Africa: Historical and anthropological perspectives, Madison: University of Wisconsin Press.

Lévi-Strauss, C. (1966) The Savage Mind, London, Weidenfeld \& Nicolson.

Lindley, A. (2009) 'Between "dirty money" and "development capital": Somali money transfer infrastructure under global scrutiny', African Affairs, 108: 519-39.

Little, P. D. (2003) Somalia: Economy without state, Oxford: International African Institute in association with James Currey.

Lourenço-Lindell, I. (2010) Africa's Informal Workers: Collective agency, alliances and transnational organizing in urban Africa, London: Zed Books.

Lund, C. (2006) 'Twilight institutions: an introduction', Development and Change, 37: 673-84.

MacGaffey, J. (1991) The Real Economy of Zaire: The contribution of smuggling and other unofficial activities to national wealth, Philadelphia: University of Pennsylvania Press.

MacGaffey, J., R. Bazenguissa-Ganga and 
International African Institute (2000) Congo-Paris: Transnational traders on the margins of the law, London/Bloomington/Oxford: International African Institute in association with James Currey and Indiana University Press.

Mamdani, M. (1996) Citizen and Subject: Contemporary Africa and the legacy of late colonialism, Princeton, NJ: Princeton University Press.

Mayer, A. (1966) 'The significance of quasi-groups in the study of complex societies', in M. Banton (ed.), The Social Anthropology of Complex Societies, London: Tavistock.

Mbembe, A. (2001) On the Postcolony, Berkeley: University of California Press.

- (2003) 'Necropolitics', Public Culture, 15: 11-40.

Meagher, K. (2010) Identity Economics: Social networks and the informal economy in Nigeria, Woodbridge and Rochester, NY: James Currey.

Médard, J.-F. (1992) 'Le "big man" en Afrique: esquisse d'analyse du politicien entrepreneur', L'Année Sociologique, 42: 167-92.

Mitchell, C. (1973) 'Networks, norms and institutions', in J. Boissevain and C. Mitchell (eds), Network Analysis: Studies in human interaction, The Hague: Mouton.

- (1974) 'Social networks', Annual Review of Anthropology, 3: 279-99.

Mkandawire, T. (2002) 'The terrible toll of post-colonial "rebel movements" in Africa: towards an explanation of the violence against peasantry', Journal of Modern African Studies, 40: 181-215.

Nordstrom, C. (1997) A Different Kind of War Story, Philadelphia: University of Pennsylvania Press.

- (2004) Shadows of War: Violence, power, and international profiteering in the twenty-first century, Berkeley and London: University of California Press.

- (2007) Global Outlaws: Crime, money, and power in the contemporary world, Berkeley: University of California Press. Nugent, P. (1995) Big Men, Small Boys and Politics in Ghana: Power, ideology and the burden of history, 1982-94, London: Pinter/Mansell.

Olukoshi, A. O. (2001) West Africa's Political Economy in the Next Millennium: Retrospect and prospect, Dakar: CODESRIA.

- (2005) 'Changing patterns of politics in Africa', in A. Boron and G. Lechini (eds), Politics and Social Movements in an Hegemonic World: Lessons from Africa, Asia and Latin America, Buenos Aires: CLASCO.

- (2010) 'Democratic governance and accountability in Africa: in search of a workable framework'. Inception workshop of the NAI research cluster on conflict, displacement and transformation, Uppsala, 28/29 October.

Podolny, J. M. and K. L. Page (1998) 'Network forms of organization', Annual Review of Sociology, 24: 57-76.

Powell, W. W. (1990) 'Neither market nor hierarchy: network forms of organization', Research in Organizational Behavior, 12: 295-336.

Reno, W. (1995) Corruption and State Politics in Sierra Leone, Cambridge: Cambridge University Press.

- (1998) Warlord Politics and African States, Boulder, CO: Lynne Rienner.

- (2010) 'Transforming West African networks for postwar recovery', Comparative Social Research, 27: 127-49.

Richards, P. (1996) Fighting for the Rain Forest: War, youth and resources in Sierra Leone, Oxford: James Currey.

Ryter, L. (1998) 'Pemuda Pancasila: the last loyalist free men of Suharto's order?', Indonesia, 66: 45-73.

Sahlins, M. D. (1963) 'Poor man, rich man, big-man, chief: political types in Melanesia and Polynesia', Comparative Studies in Society and History, 5: 285-303.

Schulte Nordholt, H. (1991) 'The Jago in the shadow: crime and "order" in the colonial state in Java', RIMA, 25: 74-91.

Schulte Nordholt, H. and M. van Till (1999) 'Colonial criminals in Java, 1870-1910', in V. L. Rafael (ed.), Figures of Criminality in Indonesia, the Philippines, and Colonial Vietnam, Ithaca, NY: SEAP/Cornell University. 
Shryock, A. (2004) Off Stage/On Display: Intimacy and ethnography in the age of public culture, Stanford, CA: Stanford University Press.

Simone, A. (2004a) 'People as infrastructure: intersecting fragments in Johannesburg', Public Culture, 16: 407-29.

- (2004b) For the City Yet to Come: Changing African life in four cities, Durham, NC: Duke University Press.

Srinivas, M. N. and A. Béteille (1964) 'Networks in Indian social structure', Man, 64: 165-8.

Taussig, M. (1992) 'Culture of terror space of death: Roger Casement's Putumayo report and the explanation of torture', in N. B. Dirks (ed.), Colonialism and Culture, Ann Arbor: University of Michigan Press.

Tilly, C. (1992) Coercion, Capital, and European States, Oxford: Blackwell.

Turner, S. (2010) Politics of Innocence: Hutu identity, conflict, and camp life, New York: Berghahn Books.

Utas, M. (2008a) 'Abject heroes: marginalised youth, modernity and violent pathways of the Liberian Civil War', in J. Hart (ed.), Years of Conflict:

Adolescence, political violence and displacement, Oxford: Berghahn Books.

- (2008b) 'Liberia beyond the blueprints: poverty reduction strategy papers, Big Men and informal networks', Lecture Series on African Security, 150.227.5.137/ upload/projects/Africa/Utas\%2oLiberia \%2oBeyond\%2othe\%2oBlueprints.pdf, accessed 11 December 2009.

— (2009) 'Malignant organisms: continuities of state-run violence in rural Liberia', in B. Kapferer and B. E. Bertelsen (eds), Crisis of the State: War and social upheaval, Oxford: Berghahn Books.

- (2010) 'The rewards of political violence: remobilizing ex-combatants in post-war Sierra Leone', in Graduate Institute of International and Development Studies (ed.), Small Arms Survey 2010: Gangs, groups, and guns, Cambridge: Cambridge University Press. Utas, M. and M. Jörgel (2008) 'The West Side Boys: military navigation in the Sierra Leone civil war', Journal of Modern African Studies, 46(3): 487-511. 